Copyright (C) 2021 by Cherkas Global University

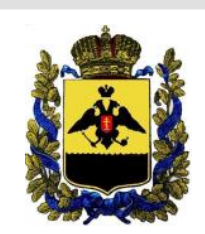

Published in the USA

Bylye Gody

Has been issued since 2006.

E-ISSN: $2310-0028$

2021. 16(4): 1972-1980

DOI: $10.13187 /$ bg.2021.4.1972

Journal homepage:

https://bg.cherkasgu.press

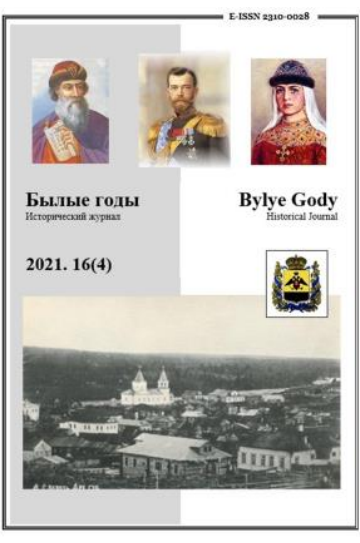

\title{
Popular Scientific Book for Children "Peoples of Russia" as a Historical Source
}

\author{
Natalia N. Seredkina a , ${ }^{\text {* }}$, Natalia N. Pimenova a , Anna A. Shpak a \\ a Siberian Federal University, Russian Federation
}

\begin{abstract}
"Peoples of Russia" is a series of ethnographic stories for children. This article analyzes the first issue of the series entitled "Deserts of the North and their nomadic inhabitants" by N. A. Aleksandrov. The book was published in 1898 and was not reprinted during the Soviet and post-Soviet times. It was also not subjected to a scientific description, while the work contains valuable historical material on the ethnography of Russia. In a form that is generally accessible for perception, N. A. Aleksandrov systematizes the historical and ethnographic material about the peoples inhabiting the North of Russia in the XIX century. The purpose of the study is to consider the image of these peoples, to study their ethnic-forming markers, from the standpoint of which the peoples are presented in the source. The research was carried out on the basis of the analysis of six ethnographic stories and the contents of the "Interpreter" section. Source analysis has become the main research method. As a result of the study, ethno-forming markers of such historical peoples of the north of Russia as the Lapps, Samoyeds, Ostyaks, Yukagirs, Chukchi, and Koryaks were identified. Ethnographic markers are manifested through the description of the appearance of members of peoples, their way of life, beliefs, traditions, rituals, social structure, economic situation, interethnic relations, in particular with Russians. It demonstrates not only the territorial remoteness of peoples from civilization, but also the decisive role of the natural and climatic conditions of the North in the formation of the culture of peoples. The systematization of historical data based on the analysis of the first issue of the "Peoples of Russia" publication substantially supplements the available information regarding the processes that took place among the northern peoples of Russia in the XIX century.
\end{abstract}

Keywords: Peoples of Russia, North, indigenous peoples, stories, ethnography of Russia, Samoyeds, Chukchi, deer, nature of the tundra, N. A. Aleksandrov.

\section{1. Введение}

Северные народы России, как и вся территория Севера, с давних времен привлекают к себе внимание историков. Наряду с официальными документами, научными отчетами, различного рода заметками в средствах массовой информации, ценность представляют и художественные научнопопулярные тексты. Одним из таких текстов выступает труд замечательного русского ученого, писателя, издателя, этнографа, художественного критика Николая Александровича Александрова (1841-1907) «Пустыни Севера и их кочующие обитатели», изданный в 1898 году. Это первый систематический труд по этнографии России, научно не описанный до настоящего времени.

Цель исследования состоит в реконструкции исторического образа народов Севера России XIX века на основе источниковедческого анализа труда «Пустыни Севера и их кочующие обитатели» Н.А. Александрова.

\footnotetext{
${ }^{*}$ Corresponding author

E-mail addresses: nnevolko@sfu-kras.ru (N.N. Seredkina), pimenovapluzhnik@mail.ru (N.N. Pimenova), annaheyy@gmail.com (A.A. Shpak)
} 


\section{2. Материалы и методы}

2.1. Исследование проведено на основе шести этнографических рассказов и раздела «Толкователь» первого выпуска издания «Народы России» - «Пустыни Севера и их кочующие обитатели» Н.А. Александрова.

2.2. Основным методом исследования стал источниковедческий анализ, предполагающий два этапа: на первом - была изучена история создания текста, его общая структура, цель автора; на втором - был проведен культурологический анализ с элементами пересказа содержания каждого из семи разделов книги. Особое внимание уделялось интерпретации описываемых событий, имеющих отношение к культуре коренных народов Севера.

\section{3. Обсуждение}

Среди первых наиболее полных описаний природно-климатических условий севера и народов, проживающих в тундре, являются труды А.Ф. Миддендорфа «Путешествие на Север и Восток Сибири» (Миддендорф, 1878) и П.И. Третьякова «Туруханский край, его природа и жители» (Третьяков, 1871). Наряду с научными отчетами полевых работ в местах компактного проживания коренных народов Севера (Копцева, 2012; Arzyutov, Kan, 2017; Копцева, Резникова, 2015; Григорьева, 2016), источниковедческую базу по истории северных народов России составляют архивные письменные источники различной направленности. К анализу документальных материалов по истории и этнографии Сибири обращаются С.Т. Гайдин, Г.А. Бурмакина (Гайдин, Бурмакина, 2019), О.Б. Степанова (Степанова, 2021). Анализу фольклорных, мифологических, шаманских текстов посвящают свои работы Е.Н. Романова, О.Е. Добжанская (Романова, Добжанская, 2019), Е.Р. Батьянова (Батьянова, 2018). Произведения национальной литературы как источник характеристики мироотношения коренных народов Севера анализируются Ж.В. Бурцевой (Бурцева, 2020), В.С. Лузаным (Лузан, 2016), О.К. Павловой (Рavlova, 2018), К.В. Резниковой, Ю.С. Замараевой (Резникова, Замараева, 2016) и другими (Середкина, 2016; Сертакова, 2016; Ситникова, 2016; Смолина, 2016). Значимость поддержания развития национальной литературы для сохранения традиционной культуры обосновывается в трудах Н.П. Копцевой, Н.Н. Середкиной (Середкина, Копцева, 2018), Ю.С. Замараевой, Н.А. Сергеевой, А.И. Филько (Замараева и др., 2018).

Издания «Народы России» Н.А. Александрова не переиздавались в советское и постсоветское время и не подвергались научному анализу. В статье Д.В. Парыгиной эта книга лишь упоминается как источник для изучения культурного наследия Арктики, ориентированный на детскую аудиторию (Парыгина, 2016).

\section{4. Результаты}

\section{1. Общая характеристика источника}

«Народы России» - это серия книг Николая Александровича Александрова. В рамках данной серии вышли три выпуска: «Пустыни Севера и их кочующие обитатели» (Вып. 1), «Инородцы лесов. Сибирь» (Вып. 2), «Инородцы лесов» (Вып. 3.).

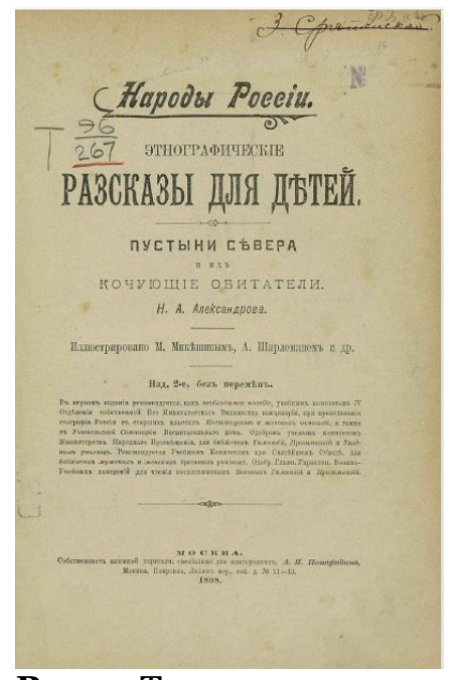

Рис. 1. Титульная страница книги

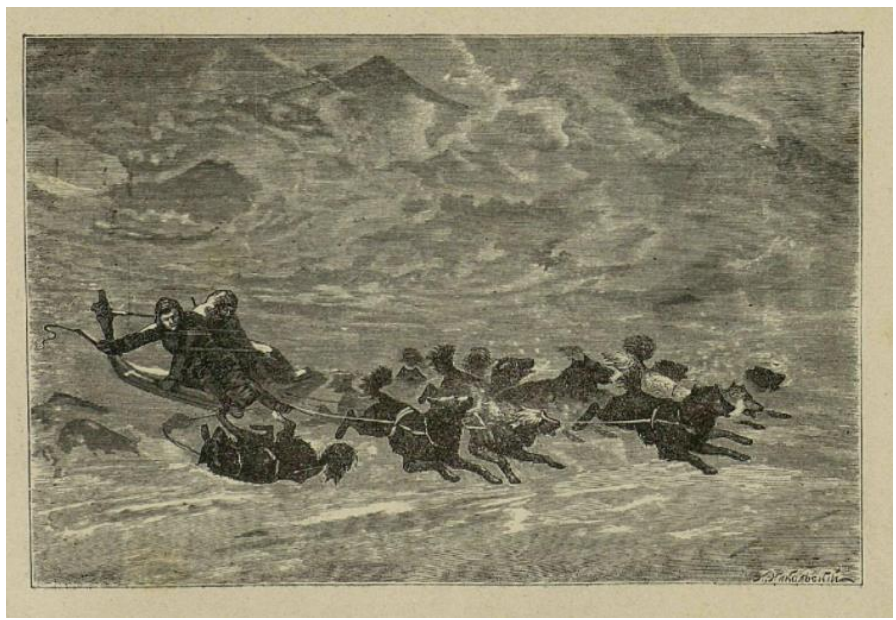

Рис. 2. Иллюстрация П. Никольского в разделе «Земля чукчей и коряков»

Объектом нашего исследования является первый выпуск. Предпосылками к его изданию послужило, по замечанию Н.А. Александрова, наличие «мизерных сведений» о народах, живущих в России среди воспитанников учебных заведений, а также отсутствие всякого понимания об этнографии России в обществе в целом (Александров, 1898: 4). 
Несмотря на то, что выпуск состоит из 6 самостоятельных этнографических рассказов, все они объединены единой логикой изложения, разворачивающейся от описания «совершенно дикой и недоступной природы тундры... к более благодатной природе...; и тут же параллельно, начиная с народов диких, бродячих и кочевых, ...к народам оседлым и цивилизованным» (Александров, 1898: 6). Каждый народ описывается с позиции ключевых для его культуры событий. Как пишет автор, «...я беру ...только то, что данный народ более всего характеризует» (Александров, 1898: 7). На протяжении первых трех рассказов сквозным персонажем выступает Кастрен, молодой путешественник. Хронологически рамки его путешествия обозначены периодом с 1838 года (начало путешествия) по 1855 год (год смерти персонажа). В четвертом рассказе таким путешественником выступает ученый естествоиспытатель Мидендорф. Началом его путешествия обозначен 1843 год. В пятом и шестом рассказах меняется характер повествования. Большое место занимают повествования от лица автора и лица сибиряков, которые обращаются к прошлому, к рассказам своих дедов о жизни на севере.

\section{2. Анализ содержания источника}

\section{Лапландцы или Лопари (осень на тундре)}

Этнографический рассказ «Лапландцы и Лопари (осень в тундре)» - это повествование о быте, обычаях, жизни лопарей, которое ведется от третьего лица. Значительное место в повествовании отводится автором описанию природы и климата тундры, называемой «пустыней». Подчеркивается ее сила перед человеком: «...тундра, точно всасывая, постепенно вбирает в себя попавшуюся жертву» (Александров, 1898: 20).

Обитатели этой «пустыни» - лопари - характеризуются как «кочующие, почти еще дикие» (Александров, 1898: 17). Живут они в «деревушке», образованной рядом жилищ, называемых «веже». Это небольшие сооружения с низкими отверстиями для входа. Конструкция веже состоит из тонких жердей и досок, «положенных в наклонном положении и таким образом, что веже шире всего становилась посередине, а на обоих концах она суживалась и образовывала две узкие боковые стены с двумя отверстиями» (Александров, 1898: 26). С целью сохранения тепла веже обкладывалась торфом. Сбоку на высоких столбах располагалась кладовая.

Из беседы Кастрена с русским промышленником читатель узнает о ряде исторических фактов миграции лопарей, в том числе о том, что они мигрировали вместе с другими финскими племенами из Азии, в частности из Алтая. По своему составу лопари делятся на кочующих и некочующих. Кочующие - живут в самой тундре. Дома и избы они не строят, а перевозят с собой доски и жерди. Оседлые же лопари строят себе дома. Они не занимаются оленеводством и живут ближе к морю. Среди лопарей есть вожак, хорошо знающий особенности местности. Он же выступил проводником и для Кастрена.

Владели лопари как своим национальным языком, так и довольно хорошо говорили на русском языке. Помимо языка, от русских, согласно рассказу, они переняли много обычаев и обрядов.

Лопарки характеризуются трудолюбивыми, прекрасными мастерицами. Лопари, наряду с охотой, занимались рыбным промыслом, началом которого считалось 24 июня, день начала весны в тундре.

Одежда у лопарей делилась на летнюю и зимнюю. Летняя - состояла из серой суконной юпы до пят и серого колпака. Зимнюю одежду составляли мешки или рубахи, называемые пески, сшитые из оленьих шкур. Одна рубаха надевалась шерстью вверх, другая - шерстью вниз. На голову надевались оленьи шапки с наушниками шерстью вверх. Они пришивались вплотную к нижней рубахе. Неотъемлемым атрибутом одежды лопарей был кожаный ремень, к которому подвязывались ножи, ключи, мошенки и разные погремушки. Самой ценной вещью был нож: «...без ножа лопарь никуда ни на шаг; с ним он даже ложится и спать» (Александров, 1898: 25). Женская одежда в целом была такая же, что и у мужчин. Единственным ее отличием был декор. Женские рубахи, или пески, декорировались яркими суконными лоскутами, которые пришивались в разных местах. Украшениями служили бусы и цепочки с крестом.

Ключевыми обрядами в рассказе названы свадьба и погребение, имеющие особый ритуальный и театрализованный характер. Несмотря на то, что лопари, согласно Кастрену, были приобщены к христианству преподобным Трифоном Печенежским еще со времен Иоанна Грозного, оставалась сильна их языческая вера.

\section{Самоеды (зима на тундре)}

Так же, как и в предыдущем рассказе, главный герой Кастрен выступил наблюдателем жизни самоедов, у которых он пробыл с конца 1842 года по ноябрь 1843 года.

Достаточно подробно описывается одежда самоедов - малица, савик (та же малица только с капюшоном), нимы (национальный вид сапог) и традиционное жилище - чум. Особое внимание обращено описанию священного места - «синекуй», где хранились у самоедов «лучшие вещи и самые лакомые съестные припасы» (Александров, 1898: 46).

Описанию религиозной картины мира самоедов также отведено значительное место. Религиозные воззрения самоедов определяли, согласно наблюдениям Кастрена, отношение к женщинам - инькам, вера в существование определенной иерархии высших существ: Нум, духи -

$$
-1974-
$$


тадебции, шаман - тадибей. Ритуализирован был также и обряд погребения. Похоронный обряд у самоедов сопровождался возложением в могилу умершего всех необходимых для жизни вещей. Такими вещами был нож умершего, хорей, которым он погонял оленей при жизни, разбитая чашка, из которой он пил. Самого умершего одевали в лучшую одежду. Считалось, что умерший будет еще несколько дней жить в могиле и вещи ему будут нужны. Над могилой возводили курган, на котором приносили в жертву любимого оленя умершего. Могила украшалась также хаге, деревянной фигурой, называемой «болванчиком». Последним действием проходил обряд кормления болванчика: «самоеды мазали свежей оленьей кровью губы болванчика, тыкали ему в рот куски оленьей печенки...» (Александров, 1898: 51).

\section{Остяки (весна на тундре)}

Путешествие героя к остякам сопровождается подробным описанием расцвета весны в тундре. Подчеркивается ее быстротечность, определяющая также и динамичный характер жизни остяков в этот период.

Основными видами деятельности у остяков называются рыболовство и охота на птиц. Это был их основной заработок, который они отдавали купцам либо в казну, либо меняли на необходимые для них вещи (как правило, хлеб и водку).

Согласно описанию, остяки были маленькими с большими головами и тонкими худыми ногами. В обществе Кастрена вели себя тихо и боязливо. По мнению автора, это отпечаток влияния сурового мира тундры.

Традиционным жилищем остяков назван «берестяной, низенький, четырехугольный чум, с высокой остроконечной крышею, сделанной из ивовых стволов, обшитых с помощью гибких древесных кореньев берестою...» (Александров, 1898: 71-72). Возле каждого чума на высоких столбах располагались традиционно кладовые. Внутри чума находились идолы, или хаге, по-остяцки называемые «лонг».

Сообщество остяков находилось в зависимости от купцов и самого князя. В казну князя остяки должны были отдавать определенную долю своего улова. Само общество остяков делилось по родам, в каждом из которых был старшина, который собирал ясак.

Верования остяков также описаны в рассказе. Самым почитаемым животным среди остяков был медведь. Клятва, произносимая с упоминанием медведя, считалась самой сильной, нарушить ее было нельзя. Сильна была также вера в идолов, с которыми обращались как с живым существом. Идола «одевали по утрам в костюм покойного, раздевали и клали спать, затем кормили, т.е. ставили во время обеда перед ними пищу» (Александров, 1898: 79). Как и самоеды, остяки клали в могилу с умершим все необходимые для жизни вещи. Считалось, что умерший живет еще в могиле три года и всеми вещами, которые были положены с ним в могилу, он пользуется, как и при жизни.

Таймурская земля и Сибирские Самоеды или Самоядь (Путешествие Мидендорфа и ловля песца)

Рассказ о Таймурской земле раскрывается через путешествие ученого естествоиспытателя Мидендорфа в 1848 году. В команде были и другие: «...ученый Брандт, один топограф и три Туруханских казака...» (Александров, 1898: 89). Описываемые события приходятся на период с апреля по октябрь.

Особое место занимает описание природных явлений, представляющих суровую сибирскую тундру как страшную, неприступную, пустынную и ужасную. В путешествии описываются такие оптические эффекты Севера как снежная слепота. Северные туманы настолько плотные, что поиск дороги мог осуществляться только строго по компасу. Представители животного мира в рассказе также упоминаются: «Они видели начало Таймурской тундры, видели у берегов белых медведей, диких оленей, на море же китов и белуг...» (Александров, 1898: 87).

Самоеды в рассказе представляются следующим образом: «Скудная жизнь, мрачная природа сделали и самый тип сибирского самоеда весьма серьезным, суровым; на вид он кажется каким-то недоступным, диким; узенькие глаза самоеда строго глядят из-под широких век и нависшего лба; безбородый, скуластый, с клоками прямых щетинистых волос на голове, он походит в иные минуты на зверя» (Александров, 1898: 90-91).

Подчеркиваются анималистические воззрения самоедов: «...медведь вовсе не зверь и что под его косматой одеждой срывается человеческий образ, одаренный свыше божественной силой и мудростью» (Александров, 1898: 91).

Быт самоедов кочевой и сравнивается опять же с мезенскими самоедами и связан с переходом оленьих стад, а также с охотой на разного пушного зверя, преимущественно песца: «...самоед придумал для него разные силки, капканы, западни, кулемки, а зачастую охотится на него с ружьем» (Александров, 1898: 92).

Повествование о путешествии Мидендорфа, помимо описания природных и климатических условий жизни на Таймурской земле, включает важные этнографические очерки о быте самоедов. Описываются тонкости охоты, в частности на песца, внешний вид самоедов и верования. Автор выбирает именно охоту на песца в качестве знаковой, так как позднее именно белая шкура песца будет знаком белой и холодной пустыни Севера для путешественника Мидендорфа. 


\section{Юкагиры (Лето на тундре и охота на оленя)}

Следующий рассказ повествует о жизни юкагиров, коренного народа, проживающего на севере Дальнего Востока. Разворачиваемые события территориально происходят на реке Анюй, притоке Колымы. Время рассказа приходится на весну и лето, когда зимние запасы кончились и юкагиры начинают охоту на дикого оленя. С этнографической точки зрения рассказ содержит особенности быта юкагиров, а именно охоты на дикого оленя.

Описываемое время - весна, но необычная, когда оленье стадо не появилось во время весеннего хода, что спровоцировало голод (Александров, 1898: 103). Орудия охоты на оленя - стрелы и нож. Юкагиры на маленьких легких лодках переплыли Анюй и спрятались в засаде за камнями. Не всегда охота на оленя была удачной. Олень ходил несколько раз: «...все помышления его (юкагира) ограничивались следующей засадой, - вторым или осенним ходом дикого оленя. От этого второго хода зависела вся пища на долгую зиму и все его существование. Второй же оленний ход, от холодных берегов Ледовитого океана опять обратно в леса...» (Александров, 1898: 106). При переходе оленя через реку юкагиры на лодках забивали поголовье оленя, а на один чум приходилось 100-150 штук оленей.

Приготовление мяса имело разные технологии: «...и только жена брала каждый день сохранявшихся оленей из вод Анюя и то вялила оленье мясо, то коптила его, то морозила» (Александров, 1898: 110).

Оленьи шкуры и рога выделывались и обменивались на необходимые для жизни вещи: хлеб, котлы и пр. (Александров, 1898: 110). Помимо охоты на оленя, пропитание состояло из трав, деревьев, рыбы, морошки, других ягод, гусей, уток, мышей, кореньев.

Жаркие дни лета предполагают тучи насекомых, юкагиры ставили «дымокуры, или большие кучи сваленного мха, листа и сырого леса, дымились, зажигаемые около пастбищ и человеческих жилищ; дым отгонял докучливую мошку, но олень, заедаемый ею, бежал, спасаясь, в воду» (Александров, 1898: 105).

Отмечаются фольклорные песни о могущественных предках: «Омаки, предки его, были народ сильный, как они говорили, вели сто лет тому назад войны с соседним храбрым народом чукчами и частью пали на войне, а частью поморила их оспа, от которой и рассеялись они...» (Александров, 1898: 105).

Рассказ знакомит читателя с таким важным аспектом жизни народа юкагиров, как охота. Все рассматривается с точки зрения необычной ситуации, в которой оказались северные народы Дальнего Востока, и как они ведут свой быт, чтобы выжить в таких природных условиях.

\section{Земля Чукчей и Коряков (Ярмарка в селе Островном)}

Повествование в этой части книги устроено в большей степени как диалог сибиряков, идущих торговать на Крайний Север и участвующих в ярмарке, которые в пути делятся историями об этих краях и их жителях. Постепенно с момента прибытия торговцев в село Островное начинает доминировать рассказ от автора. В первой его части взгляды торговцев-сибиряков и автора на особенности жизни северян кажутся общими, но как только их голоса разделяются, становится явным, что автор не разделяет взгляда на чукчей и коряков как на дикарей.

В этом рассказе также тщательно описаны климатические и природные условия. Место, куда держат путь торговцы из Колымска, названо краем света. Территория жизни чукчей и коряков описана как предельно обширная - от Колымы до Берингова пролива, от Камчатки до Ледовитого океана, при этом чукчи живут севернее реки Анадырь, а коряки - южнее. Образ этих мест из рассказов торговцев - практически необитаемый, непригодный для жизни. С удивлением путники делятся тем, что и в этих условиях живут люди, и отмечают, что в выносливости им с хозяевами этих мест не сравниться.

В описании образа жизни акцентирована роль оленя: говорится, что у чукчей и коряков есть по 4-5 тысяч оленей и корм для оленей - самое важное для чукчей, «т.к. олень и одевает, и кормит, и возит его». В отношении социального устройства путники дают понять, что чукчи очень своенравны и власти не признают («ясака не платят»), что даже их предводители не являются настоящей властью и что авторитет шаманов также не абсолютен, а решения принимаются племенем совместно. Речь идет в основном о кочующих северянах. Отмечается, что оседлые чукчи и коряки - бедные, находятся в зависимости от кочевых, не имеют оленей и ездят на собаках. Живут они охотой и промыслом. В рассказе описаны способы охоты на моржей и тюленей в воде и на берегу, а также хитрый способ охоты на волка. Из деталей культуры северных народов интерес представляет детальное описание мужского костюма чукчей и двух обрядов - свадебного обряда коряков и похоронного обряда чукчей. С акцентом на почтение и внимание к покойному описывается погребение.

Пока торговцы находятся в пути, образы этих северных народов предстают перед читателем весьма экзотичными и даже пугающими («...на людей не походили: губы у всех были прорезаны, а из прорезей этих торчали моржовые клыки»). Описываются чукчи и как народ воинственный («Якутские воеводы когда пошли на них с войском, так чукчи впереди коряков, впереди всех шли и дрались как бешеные»), и как разбойничающий («только и слышно, что чукчи грабят и разбойничают»), и как те, с кем дело иметь даже опасно («так он тут же того пикой и пырнет»). Когда в тексте встреча торговцев и представителей местных народов состоялась, то автор начинает 
описывать их иным образом, в том числе называет чукчей и коряков «северными атлетами». Среди качеств чукчей описываются, например, предприимчивость и ловкость в ведении дел: «...что Чукчи предприимчивее коряков, и что они торгуют даже с Америкой. Туда переплывают они через Берингов пролив на своих легких лодках, или байдарах, и там выменивают у американцев меха и моржовые клыки» (Александров, 1898: 116). Постепенно в тексте нарастает выражение восхищения северянами. Изменение доминирующей оценки в тексте становится явным в момент жертвенного самоубийства тиуна. Торговцы-сибиряки расценивают самоубийство предводителя как проявление дикости («разбойники, душегубцы»). Автор же описывает это событие и реакцию соплеменников как проявление взаимовыручки и поступки, достойные героев: «Но коряки и другие туземцы смотрели на это убийство с благоговением, а сам тиун вполне признавал себя обязанным исполнить этот долг даже при последних предсмертных судорогах. ...Чукчи, видя его мучения, ...доколотили тиуна заботливой и дружеской рукой» (Александров, 1898: 129). В целом народ чукчей и коряков автором характеризуется как наделенный лучшими качествами: «...воинственный, борющийся с этою природой и нисколько не страшащийся ее, умный, смелый и отчаянный народ чукчей и коряков» (Александров, 1898: 130). В том числе качеством искренней веры: «...чукчи думали, что душа тиуна возносится вместе с этим пламенем прямо на небо» (Александров, 1898: 129). Коренные народы противопоставлены русским торговцам в тексте не только за счет того, что оценка сибиряков как людей со стороны оказывается далекой от того, как и что происходит на самом деле. Когда речь заходит о торговом азарте, именно приезжие предстают в описаниях автора немного дикарями, тогда как чукчи ведут себя «с какою-то непоколебимой важностью» (Александров, 1898: 121).

Раздел «Толкователь» - существенная часть издания, занимающая 26 страниц и подробно отвечающая на ряд вопросов. Цель толкователя - охарактеризовать и явления природы Крайнего Севера, и культуры живущих в нем народов. В толкователе 16 разделов, они расположены от более общих вопросов к частным: от краткого введения в то, что представляет собой этнография и на какие группы учеными разделяется население нашей планеты, до особенностей северной природы (длительность лета, северное сияние, особенности флоры и фауны тундры) и культуры (здесь освещены, вероятно, самые волнующие европейского обывателя вопросы - о том, в чем могут заключаться причины людоедства, почему шаманы раздражительны, а северяне любят табак и едят мухоморы, как появилась традиция татуировать лица). Изложение ответов на обозначенные в заглавиях вопросы включает обязательные ссылки на исследователей и их высказывания, при этом тексты ориентированы на восприятие неподготовленной аудиторией, и пояснения даны емко и достаточно простым языком.

\section{5. Заключение}

Анализ труда «Пустыни Севера и их кочующие обитатели» Н.А. Александрова позволил сконструировать исторический образ народов Севера России XIX века как особых народностей, жизнь и культура которых всецело зависима от природно-климатических условий тундры. Описанию суровых условий жизни на Севере отведено значительное место в издании. Северные народы показаны в своей динамике развития. Им не чужды процессы трансформации, которые связаны с принятием христианства и развитием практики товарообмена с русскими торговцами. При этом языческая вера показана как определяющая в жизни северных народов. Автором в текстах последовательно продемонстрирована позиция ученого, способного понять иную культуру как функционирующую должным, но особым образом, увидеть в представителях коренных народов «не дикарей» и обосновать причины того, что не все народы находятся на одинаковом этапе развития, показать ценность описываемых культур.

\section{6. Благодарности}

Работа выполнена в рамках реализации проекта РФФИ № 21-09-43014 «"Великое братство народов" (В.Н. Увачан): национальная политика СССР по отношению к коренным малочисленным народам Севера в Эвенкийском и Таймырском национальных (впоследствии - автономных) округах Красноярского края в 1920-1970-е гг.».

\section{Литература}

Александров, 1898 - Александров Н.A. Народы России: этнографические рассказы для детей. Пустыни Севера и их кочующие обитатели. Москва, 1898. 156 с.

Батьянова, 2018 - Батьянова Е.П. Визуальные образы в мировоззрении, мифологии и фольклоре народов Севера // Вестник угроведения. 2018. № 8 (4). С. 695-704.

Бурцева, 2020 - Бурцева Ж.В. Крайний Север как геопоэтический образ в литературе малочисленных народов Севера Якутии // Вестник Удмуртского университета. 2020. № 30 (2). C. $337-341$.

Григорьев, 2016 - Григорьев С.A. Общественно-политический аспект этнического развития коренных малочисленных народов Северо-Востока России в XX веке // Исторические, философские, 
политические и юридические науки, культурология и искусствоведение. Вопросы теории и практики. 2016. № 10 (72). С. 71-74.

Замараева и др., 2018 - Замараева Ю.С., Сергеева Н.А., Филько А.И. Меры по сохранению языка коренных малочисленных народов по результатам полевых и научных исследований в Эвенкийском муниципальном районе Красноярского края // Журнал СФУ. Гуманитарные науки. 2018. № 114. С. 679-694.

Коренные малочисленные народы..., 2012 - Коренные малочисленные народы Севера и Сибири в условиях глобальных трансформаций (на материале Красноярского края). Ч. 1: Концептуальные и методологические основы исследования. Этнокультурная динамика коренных малочисленных народов Красноярского края / Отв. ред. Н.П. Копцева. Красноярск, 2012. 639 с.

Лузан, 2016 - Лузан B.C. Советский и постсоветский периоды в истории детской литературы на языках коренных малочисленных народов Севера, Сибири и Дальнего Востока // Журнал СФУ. Гуманитарные науки. 2016. № 9 (9). С. 2060-2070. 1878.

Миддендорф, 1878 - Миддендорф А.Ф. Путешествие на Север и Восток Сибири. В 2 ч. СПб.,

Парыгина, 2016 - Парысина Д.В. Ресурсы Президентской библиотеки как источниковая база для изучения культурного наследия Арктики // Полярные чтения на ледоколе «Красин». 2016. Т. 3. C. 160-172.

Резникова, Замараева, 2016 - Резникова К.В., Замараева Ю.С. Долганская детская литература: история и специфика // Журнал СФУ. Гуманитарные науки. 2016. № 9 (9). С. 2022-2043.

Романова, Добжанская, 2019 - Романова E.H., Добжанская O.E. Антропология холода: методология, концепции, образы (на материалах культурных традиций коренных народов Севера и Арктики) // Вестник Томского государственного университета. Журнал культурологии и искусствоведения. 2019. № 35. С. 255-263.

Середкина, 2016 - Середкина Н.Н. Эвенкийская детская литература: история и специфика // Журнал СФУ. Гуманитарные науки. 2016. № 9 (9). С. 1994-2004.

Середкина, Копцева, 2018 - Середкина Н.Н., Копцева Н.П. Мировые и российские практики в области сохранения и воспроизводства языков коренных малочисленных народов Севера // Журнал СФУ. Гуманитарные науки. 2018. № 11 (12). С. 2056-2077.

Сертакова, 2016 - Сертакова E.A. Ненецкая детская литература: история и специфика // Журнал СФУ. Гуманитарные науки. 2016 . № 9 (9). С. 2013-2021.

Ситникова, 2016 - Ситникова А.А. Нганасанская детская литература: история и специфика // Журнал СФУ. Гуманитарные науки. 2016. № 99). С. 2005-2012.

Смолина, 2016 - Смолина М.Г. Особенности детской художественной литературы коренных народов // Журнал СФУ. Гуманитарные науки. 2016. № 9 (9). С. 1945-1976.

Степанова, 2021 - Степанова О.Б. Рукопись Е.Д. Прокофьевой «Рыболовство тазовскотуруханских селькупов» из архива Музея антропологии и этнографии (Кунсткамера) как источник по истории и этнографии Сибири. 1920-1960-е гг. // Вестник архивиста. 2021. № 1. С. 168-180.

Третьяков, 1871 - Третьяков П.И. Туруханский край, его природа и жители. СПб., 1871. 316 с.

Arzyutov, Kan, 2017 - Arzyutov D.V., Kan S.A. The Concept of the "Field" in Early Soviet Ethnography: A Northern Perspective // SIBIRICA. 2017. № 16 (1). Pp. 31-74.

Gaidin, Burmakina, 2019 - Gaidin S.T., Burmakina G.A. (2019). Proposals to Protect the Interests of the Indigenous Peoples of the Turukhansk Region in 1822-1917 // Bylye Gody. 52(2): 634-644.

Koptseva, Reznikova, 2015 - Koptseva, N.P., Reznikova, K.V. (2015). Clarification of the Reasons for the Ethnic Migration of the Northern Selkups on the Basis of the Historical Memory of the Indigenous Ethnic Groups of the Turukhansk District of the Krasnoyarsk Territory. Bylye Gody. 38(4): 1028-1038.

Pavlova, 2018 - Pavlova O. K. Mythological Image in Olonkho of the North-Eastern Yakut Tradition: Sacred Tree // Journal of History Culture and Art Research. 2018. 7(3): 79-87.

\section{References}

Aleksandrov, 1898 - Aleksandrov, N.A. (1898). Narody Rossii: etnograficheskie rasskazy dlya detei. Pustyni Severa i ikh kochuyushchie obitateli [The peoples of Russia: ethnographic stories for children. Deserts of the North and their nomadic inhabitants]. Moscow, 156 p. [in Russian]

Arzyutov, Kan, 2017 - Arzyutov, D.V., Kan, S.A. (2017). The Concept of the "Field" in Early Soviet Ethnography: A Northern Perspective. SIBIRICA. 16(1): 31-74.

Bat'yanova, 2018 - Bat'yanova, E.P. (2018). Vizual'nye obrazy v mirovozzrenii, mifologii i fol'klore narodov Severa [Visual images in the worldview, mythology and folklore of the peoples of the North]. Vestnik ugrovedeniya. 8(4): 695-704. [in Russian]

Burtseva, 2020 - Burtseva, Zh.V. (2020). Krainii Sever kak geopoeticheskii obraz v literature malochislennykh narodov Severa Yakutii [The Far North as a geopoetic image in the literature of the small peoples of the North of Yakutia]. Vestnik Udmurtskogo universiteta. 30(2): 337-341. [in Russian]

Gaidin, Burmakina, 2019 - Gaidin, S.T., Burmakina, G.A. (2019). Proposals to protect the interests of the indigenous peoples of the Turukhansk region in 1822-1917. Bylye Gody. 52(2): 634-644. 
Grigor'ev, 2016 - Grigor'ev, S.A. (2016). Obshchestvenno-politicheskii aspekt etnicheskogo razvitiya korennykh malochislennykh narodov Severo-Vostoka Rossii v XX veke [Socio-political aspect of the ethnic development of the indigenous peoples of the North-East of Russia in the XX century]. Istoricheskie, filosofskie, politicheskie i yuridicheskie nauki, kul'turologiya $i$ iskusstvovedenie. Voprosy teorii $i$ praktiki. 10(72): 71-74. [in Russian]

Koptseva, Reznikova, 2015 - Koptseva, N.P., Reznikova, K.V. (2015). Clarification of the Reasons for the Ethnic Migration of the Northern Selkups on the Basis of the Historical Memory of the Indigenous Ethnic Groups of the Turukhansk District of the Krasnoyarsk Territory. Bylye Gody. 38(4): 1028-1038.

Korennye malochislennye narody..., 2012 - Korennye malochislennye narody Severa i Sibiri v usloviyakh global'nykh transformatsii (na materiale Krasnoyar. kraya). Ch. 1: Kontseptual'nye i metodologicheskie osnovy issledovaniya. Etnokul'turnaya dinamika korennykh malochislennykh narodov Krasnoyarskogo kraya [Indigenous small peoples of the North and Siberia in the context of global transformations (on the material of the Krasnoyarsk Territory). Part 1: Conceptual and methodological foundations of the study. Ethnocultural dynamics of the indigenous peoples of the Krasnoyarsk Territory]. Otv. red. N. P. Koptseva. Krasnoyarsk, 639 p. [in Russian]

Luzan, 2016 - Luzan, V.S. (2016). Sovetskii i postsovetskii periody v istorii detskoi literatury na yazykakh korennykh malochislennykh narodov Severa, Sibiri i Dal'nego Vostoka [Soviet and post-Soviet periods in the history of children's literature in the languages of the indigenous peoples of the North, Siberia and the Far East]. Zhurnal SFU. Gumanitarnye nauki. 9(9): 2060-2070. [in Russian]

Middendorf, 1878 - Middendorf, A.F. (1878). Puteshestvie na Sever i Vostok Sibiri [Travel to the North and East of Siberia]. V 2 ch. Sankt-Peterburg. [in Russian]

Parygina, 2016 - Parygina, D.V. (2016). Resursy Prezidentskoi biblioteki kak istochnikovaya baza dlya izucheniya kul'turnogo naslediya Arktiki [Resources of the Presidential Library as a source base for studying the cultural heritage of the Arctic]. Polyarnye chteniya na ledokole «Krasin». 3: 160-172. [in Russian]

Pavlova, 2018 - Pavlova, O.K. (2018). Mythological Image in Olonkho of the North-Eastern Yakut Tradition: Sacred Tree. Journal of History Culture and Art Research. 7(3): 79-87.

Reznikova, Zamaraeva, 2016 - Reznikova, K.V., Zamaraeva, Yu.S. (2016). Dolganskaya detskaya literatura: istoriya i spetsifika [Dolgan children's literature: history and specifics]. Zhurnal SFU. Gumanitarnye nauki. 9(9): 2022-2043. [in Russian]

Romanova, Dobzhanskaya, 2019 - Romanova, E.N., Dobzhanskaya, O.E. (2019). Antropologiya kholoda: metodologiya, kontseptsii, obrazy (na materialakh kul'turnykh traditsii korennykh narodov Severa i Arktiki) [Anthropology of cold: methodology, concepts, images (based on the materials of cultural traditions of the indigenous peoples of the North and the Arctic)]. Vestnik Tomskogo gosudarstvennogo universiteta. Zhurnal kul'turologii i iskusstvovedeniya. 35: 255-263. [in Russian]

Seredkina, 2016 - Seredkina, N.N. (2016). Evenkiiskaya detskaya literatura: istoriya i spetsifika [Evenk children's literature: history and specificity]. Zhurnal SFU. Gumanitarnye nauki. 9(9): 1994-2004. [in Russian]

Seredkina, Koptseva, 2018 - Seredkina, N.N., Koptseva, N.P. (2018). Mirovye i rossiiskie praktiki v oblasti sokhraneniya i vosproizvodstva yazykov korennykh malochislennykh narodov Severa [World and Russian practices in the field of preservation and reproduction of the languages of the indigenous peoples of the North]. Zhurnal SFU. Gumanitarnye nauki. 11(12): 2056-2077. [in Russian]

Sertakova, 2016 - Sertakova, E.A. (2016). Nenetskaya detskaya literatura: istoriya i spetsifika [Nenets children's literature: history and specificity]. Zhurnal SFU. Gumanitarnye nauki. 9(9): 2013-2021. [in Russian]

Sitnikova, 2016 - Sitnikova, A.A. (2016). Nganasanskaya detskaya literatura: istoriya i spetsifika [Nganasan children's literature: history and specificity]. Zhurnal SFU. Gumanitarnye nauki. 9(9): 2005-2012. [in Russian]

Smolina, 2016 - Smolina, M.G. (2016). Osobennosti detskoi khudozhestvennoi literatury korennykh narodov [Features of Indigenous Children's Fiction]. Zhurnal SFU. Gumanitarnye nauki. 9(9): 1945-1976. [in Russian]

Stepanova, 2021 - Stepanova, O.B. (2021). Rukopis' E.D. Prokof'evoi «Rybolovstvo tazovskoturukhanskikh sel'kupov» iz arkhiva Muzeya antropologii i etnografii (Kunstkamera) kak istochnik po istorii i etnografii Sibiri. 1920-1960-e gg. [The manuscript of ED Prokofyeva "Fishing of the Taz-Turukhan Selkups" from the archives of the Museum of Anthropology and Ethnography (Kunstkamera) as a source on the history and ethnography of Siberia. 1920-1960s]. Vestnik arkhivista. 1: 168-180. [in Russian]

Tret'yakov, 1871 - Tret'yakov, P.I. (1871). Turukhanskii krai, ego priroda i zhiteli [Turukhansk region, its nature and inhabitants]. St. Petersburg. 316 p. [in Russian]

Zamaraeva i dr., 2018 - Zamaraeva, Yu.S., Sergeeva, N. A., Fil'ko, A.I. (2018). Mery po sokhraneniyu yazyka korennykh malochislennykh narodov po rezul'tatam polevykh i nauchnykh issledovanii $\mathrm{v}$ Evenkiiskom munitsipal'nom raione Krasnoyarskogo kraya [Measures to preserve the language of indigenous minorities based on the results of field and scientific research in the Evenk municipal district of the Krasnoyarsk Territory]. Zhurnal SFU. Gumanitarnye nauki. 11(4): 679-694. [in Russian] 


\section{Научно-популярное издание для детей «Народы России» как исторический источник}

Наталья Николаевна Середкина а, *, Наталья Николаевна Пименова а, Анна Андреевна Шпак а

а Сибирский федеральный университет, Российская Федерация

Аннотация. «Народы России» - это серия этнографических рассказов для детей. В данной статье анализируется первый выпуск серии под названием «Пустыни Севера и их кочующие обитатели» Н.А. Александрова. Книга была издана в 1898 году и не переиздавалась в советское и постсоветское время. Она не подвергалась также научному описанию, тогда как труд содержит ценный исторический материал по этнографии России. В общедоступной для восприятия форме Н.А. Александров систематизирует историко-этнографический материал о народах, населяющих Север России в XIX веке. Цель исследования состоит в рассмотрении образа данных народностей, изучении их этнообразующих маркеров, с позиции которых народы представлены в источнике. В работе проведен анализ шести этнографических рассказов и содержания раздела «Толкователь». Основным методом исследования стал источниковедческий анализ. В результате исследования выявлены этнообразующие маркеры таких исторических народов севера России, как лопари, самоеды, остяки, юкагиры, чукчи, коряки. Этнографические маркеры проявлены через описание внешности представителей народов, их быта, верований, традиций, обрядов, социальной структуры, экономического положения, межэтнических отношений, в частности с русскими. Демонстрируется не только территориальная удаленность народов от цивилизации, но и определяющая роль природноклиматических условий Севера в формировании их культуры. Систематизация данных исторических сведений на основе анализа первого выпуска издания «Народы России» существенно дополняет имеющиеся сведения относительно тех процессов, которые происходили среди северных народностей России в XIX веке.

Ключевые слова: народы России, Север, коренные народы, рассказы, этнография России, самоеды, чукчи, олени, природа тундры, Н.А. Александров.

\footnotetext{
* Корреспондирующий автор Адреса электронной почты: nnevolko@sfu-kras.ru (H.H. Середкина), pimenovapluzhnik@mail.ru (Н.Н. Пименова), annaheyy@gmail.com (А.А. Шпак) 